\title{
The Inadequacy of Post-Development Theory to the Discourse of Development and Social Order in the Global South
}

\author{
Felix O. Olatunji \\ Ladoke Akintola University of Technology, Ogbomoso
}

\section{Anthony I. Bature}

Federal University, Wukari

\begin{abstract}
The post-development theorists argue that certain characteristics of the 'Western' ways of talking about and representing the non-West should be understood as ideological projections rather than as scientific knowledge about people and places elsewhere. To these theorists, the ways of conceiving and representing development that are closely bound to the North's development agencies and programs reveal more about the selfaffirming ideologies of the Global North than insights into the peoples of the rest of the world. In addition, the post-development scholars take up the position that development has less to do with human improvement and more to do with human control and domination. This theory suggests that societies at the local level should be allowed to pursue their own development path as they perceive it without the influences of global capital and other modern choices, and thus a rejection of the entire paradigm from Eurocentric model and the advocation of new ways of thinking about the non-Western societies. However, this developmental model for the societies of the Global South, especially Africa, is inefficient because it is a kind of cultural relativism, which is capable of veering into fundamentalism and does not allow for mutual borrowing. The thrust of this study lies basically in presenting that a combination of cultural knowledge and Western development theories through an adaptation of post-development model is needed for development and social order in Africa. This means that an all-inclusive model encapsulating life promotion and centred on human should be adopted as a development model for Africa.
\end{abstract}

Social Evolution \& History, Vol. 18 No. 2, September 2019 229-243

(C) 2019 'Uchitel' Publishing House

DOI: $10.30884 / \mathrm{seh} / 2019.02 .12$ 


\section{A CONCEPTUAL ANALYSIS OF POST-DEVELOPMENT THEORY}

In the $1990 \mathrm{~s}$, the post-development theorists argued against modernization and development for its reductionism, universalism, and ethnocentricity, that is, examining development from the 'top-bottom' approach, which identifies that societies of the Global South should borrow essentially from the developed societies. While the post-development theorists proffer the discussion to be seen and examined from the 'bottom up' approach as Gilbert Rist writes that, "it is recognised that "development" has to be built "from the bottom up", and that its medium-range objectives may vary from one society to the next' (Rist 2008). This approach of the post-development theorists lies in the interest not in development alternatives, but in alternatives to development and thus a rejection of the entire paradigm from Eurocentric model and the advocation of new ways of thinking about the non-Western societies. Post-development suggests that we allow societies at the local level to pursue their own development path as they perceive it without the influences of global capital or other modern choices and forces.

Post-development theorists like Rist, Escobar, Rahnema, Bawtree, Kothari, and Minogue among others based their discourse on the critical analysis of development. While earlier theories of development like dependency and modernisation usually focused on inadequacies that prevented the achievement of development among societies of the South, the post-development theory rejected the totality of entire paradigm and denounced it as a myth. They (post-development theorists) argue that development has been seen essentially from non-Western societies into their diverse deficiencies as regions in need of modernisation according to the models set by the Western societies. The post-development theory has also been characterised as 'beyond development' and 'anti-development' for its disruption of development's reductive nature.

Rist avers that

'development' problematics is inscribed in the very core of the Western imaginary. That growth or progress should be able to continue indefinitely - that is the idea which radically distinguishes Western culture from all others. This characteristic, as strange as it is modern, sets up between nations a division far greater than all those forged in the course of history to justify the ostensible superiority of the West (Rist 2008: 254).

The post-development theorists' argument, according to Lauren Karplus, is that the traditional concept of development is authoritarian in nature and technocratic in execution; that is, whoever decides what development is and how to achieve it is typically in a position of power (Karplus 2014: 5).

Stefan Andreasson postulates that 'post-development emphasizes the damage to local cultures, and the ways in which man relates to other hu- 
man beings and the natural world of which he of course is an integral part, in an age of increasing commodification, individualism, competition and, consequently, alienation' (Andreasson 2007: 8-9). Here, there is the quest for understanding of development not how to deliver development interventions and to minimize the failure of development as enshrined in the tenets of other theories of development; the post-development theorists believe that no amount of analyses will make the development agenda a success. They argue that the problem with development is not about how it is implemented, but rather that development itself is a flawed concept which should be eliminated from the discourse on human progress. It is also on the notion of development avowed effects on local or indigenous cultures that post-development theorists are championing against since it is purely ethnocentric and racial in nature and discourse, saying that it must be rejected not merely on account of its results but because of its intentions, its world-view and mindset, using Pieterse's analogy.

Jan Pieterse identified the post-development with an alternative form of development and examined it as a roving critique of mainstream development, shifting in position as the latter shifts; as a loosely interconnected series of alternative proposals and methodologies; or as an alternative development paradigm, implying a definite theoretical break with mainstream development. It can be viewed as concerned with local development, with alternative practices on the ground, or as an overall institutional challenge, and part of a global alternative (Pieterse 2001: 74). He raises a fundamental question against the alternative form of development post-development - as how alternative is it? What is different from the new alternative models and the so-called mainstream models, which are being castigated by the post-development theorists? Is it because of the methodologies, agents and objectives that the alternative model is different from the mainstream? Does it mean that the development, to be of alternative model, is to be people-centered, endogenous and self-reliant to use Nyerere's dictum? According to Pieterse's analysis, 'over the years alternative development has been reinforced by and associated with virtually any form of criticism of mainstream developmentalism, such as anti-capitalism, Green thinking, feminism, ecofeminism, democratization, new social movements, Buddhist economics, cultural critiques, and poststructuralist analysis of development discourse. 'Alternative' generally refers to three spheres - agents, methods and objectives or values of development. Alternative development is the terrain of citizen, or 'Third System' politics, the importance of which is apparent in view of the failed development efforts of government (the prince or first system) and economic power (the merchant or second system)' (Ibid.: 85).

This model of development, according to Pieterse, ought to be endogenous as it is not a matter of importing external models from other societies. This endogenous nature takes everything from within in order 
to cater for all aspects of development that will be beneficial to people of such society or community. To him, self-reliance, then, does not simply concern the means but the end of development: the goals and values of development are to be generated from within (Pieterse 2001: 86). ${ }^{1}$ That is, an endogenous outlook is significant and important to post-development, which is seen as an alternative model to the Westernized models that are been deconstructed. Peet and Hartwick write in support of the claim above that post-developmentalism rejects the way of thinking and the mode of living produced by modern development in favor of revitalized versions of non-modern, usually non-Western, philosophies and cultures. From this view, modern Western development is destructive rather than generative, a force to be resisted rather than welcomed (Peet and Hartwick 2009: 230). While Elliot Siemiatycki in Post-Development at a Crossroad: Towards a 'Real' Development quotes Maiava's analysis that what to term as a real development will involve

... indigenous people determining their own future, confident, not intimidated, but free people determining what they want to do and doing it for themselves, exercising agency, actively moving forward to create better lives and improve their well-being according to their own priorities and criteria as they have done for millennia (Siemiatycki 2005: 58).

Matthews Sally avers that 'the problem, from the perspective of postdevelopment theorists, is not that the project of development was poorly implemented and that it is necessary to find a better way to bring it about, but that the assumptions and ideas that are core to development are problematic and so improved implementation is not the answer' (Matthews 2004: 375). The problem with this kind of model is that it disregards the dialectics of modernity as Pieterse (2001: 110) adds 'Post-development is based on a paradox. While it is clearly part of the broad critical stream in development, it shows no regard for the progressive potential and dialectics of modernity - for democratization, soft power technologies, reflexivity', and a possible return to ethnic chauvinism and primordial ties. In line with the view raised above, he opines that

'Post-development' is misconceived because it attributes to 'development' a single and narrow meaning, a consistency which does not match either theory or policy, and thus replicates the rhetoric of developmentalism, rather than penetrating and exposing its polysemic realities. It echoes the 'myth of development' rather than leaving it behind. Post-development makes engaging contributions to collective conversation and reflexivity about development and as such contributes to philosophies of change, but its contribution to politics of change is meager. While the shift toward cultural sensibilities that accompanies this perspective is a welcome move, the plea for 'people's culture' or indigenous culture can lead, if not to ethnochauvinism and 'reverse orientalism, to reification of both culture and locality or people (Pieterse 2001: 111). ${ }^{2}$ 
Rist's critique of post-development theory is precisely that 'their celebration of initiatives that break with the dominant model is the mark of a kind of anti-modernist romanticism or a dangerous cultural relativism, which is capable of veering into neo-populism or even support for all manner of fundamentalisms' (Rist 2008: 259). This negates the idea of borrowing no matter how little from other backgrounds as no society can stand on its own without the support of others. In this constitutive perspective, development involves expansion of these and other basic freedoms - democracy, equality/equity, fundamental human rights, and good governance among others.

While societies and economies of the Global South do not necessarily have to develop according to Western ideas, the post-development theory provides limited practicable and practical alternatives to override and replace foreign assistance. This is another major set-back to the opinions and views of post-development theorists as developing societies still look and so many times beg for foreign and external aids even with some strings fully attached. The question still remains: what will be the source(s) of these alternatives to development as against the Western models? Foreign or external aids may be provided in the form of assistance from diverse groups and institutions like the G8, the Bretton Woods institutions and others.

Apart from the above, the post-development theorists suppose that the rich can never lift the poor (peoples and societies) from the pangs of poverty, and that they need to address their own problems using their own ideologies and ideas, and that they need to develop themselves rather than relying excessively on foreign aids. But the negativity still remains that the poorest of the poor will still struggle to meet their basic needs in the short-time frame. This poses great dangers on how people and societies of the Global South will get out of the quagmire they have found themselves mired in. Also, this is the fact that the societies and economies of the Global South are not homogeneous in nature as the staggering heterogeneity of African societies (cultures, languages, histories, and traditions) receives marginal attention in the discursive practice of development. The basic thrust of modern development scholarship and application returns to the essential notions of Africa's inadequate characteristics of heterogeneity, which is also a fundamental problem in the quest for alternative development as different from the Western models and hegemonies.

AN INCURSION INTO ARTURO ESCOBAR'S ETHNOGRAPHIC MODEL

Arturo Escobar believes that 'the development was and continues to be for the most part a top-down, ethnocentric, and technocratic approach that treats people and cultures as abstract concepts, statistical figures to be 
moved up and down in the charts of "progress"... It comes as no surprise that development became a force so destructive to Third World cultures, ironically in the name of people's interests' (Escobar 1999: 382). Uma Kothari and Martin Minogue aver that 'development is riddled with paradoxes. While it appears on the face of things to be very much characterized by a set of highly practical concerns, few subjects are more be devilled by contested theories. Development undoubtedly takes place in some place, as measured by shifts in economic growth; relative poverty and inequality have also increased. And the more precisely we try to identify coherent theories and measure practical changes, the less confidence we have in the predictability of future events, particularly on a global scale' (Kothari and Minogue 2002: 1).

The discourse about development from the argument of Escobar is summed up by him as he opines that,

I propose to speak of development as a historically singular experience, the creation of a domain thought and action, by analyzing the characteristics and interrelations of the three axes that define it: the forms of knowledge that refer to it and through which it comes into being and is elaborated into objects, concepts, theories, and the like; the system of power that regulates its practice; and the forms of subjectivity fostered by this discourse, those through which people come to recognize themselves as developed or underdeveloped (Escobar 1995: 10).

This opinion of Escobar is geared towards the understanding of development from its opposite, that is, underdevelopment and untold hardships that societies of the Global South experience, which are not limited only to poverty, impoverishment, exploitation, famine, violence and wars, among others.

In understanding and explaining development from its conceptualisations from the views of the Global North and Global South, he deals with the dichotomy and problem of poverty, which is affecting large number of Africans, Asians and the Latinos. Poverty was a major discovery immediately after the post-second world war of 1939-1945. The discourse of poverty as affecting the three worlds - Asia, Africa and the Latin America - according to Escobar 'brought into existence new discourses and practices that shaped the reality to which they referred. That the essential trait of the third World was its poverty and that the solution was economic growth and development became self-evident, necessary, and universal truths... It accounts for the 'developmentalisation' of the third World. Its progressive insertion into a regime of thought and practice in which certain interventions for the eradication of poverty became central to the world order' (Escobar 1995: 21).

In his analysis of development discourse from the early post-World War II period to the present, Escobar engages in an analysis of the emergence of underdevelopment as a notion of post-World War II economic development theories, which are classical, neoclassical, Keynesian and 
growth economic theories respectively, leading to the emergence of a new strategy by the Western hegemonic structure, which

was not due to theoretical, institutional, or methodological advances. It was due to the fact that a certain historical conjuncture transformed the mode of existence of economic discourse, thus making possible the elaboration of new objects, concepts, and methodologies. Economics was called upon to reform societies perceived as underdeveloped, based on a new grid for theoretical interpretation and new technologies for social management (Escobar 1995: 84).

He believes that for the less-developed societies to develop, they must first scratch move beyond modernity, which essentially, is encapsulated in neoliberalism today since such models of the Western hegemony exacerbates the problems in the societies in the Global South. This means that there is a need for the deconstruction of all forms of Western developmental models in order to seek for the alternatives to development from within. This will put an end to the ongoing struggle for the development in the realms of Western societies, which in any way has hardly served the interests of the people in non-Western societies. In his argument, Escobar projects that:

Development was not merely the result of the combination, study, or gradual elaboration of these elements (technology, population and resources, monetary and fiscal policies, industrialization and agricultural development, commerce and trade); nor the product of the introduction of new ideas; nor the effect of the new international organizations or financial institutions. It was rather the result of the establishment of a set of relations among these elements, institutions, and practices and of the systemitization of these relations to form a whole... And to understand development as a discourse, one must look not at the elements themselves but at the system of relations established among them. It is this system that allows the systematic creation of objects, concepts, and strategies; it determines what can be thought and said (Escobar 1995: 40).

In fact, development as it has been argued by other scholars, ought to be about the people (to use Ade-Ajayi's phrase) 'The most important exclusion, however, was and continues to be, what development was supposed to be all about people' (Escobar 1997: 91).

Eventually, the significance and importance attached to history and culture in the quest for authentic development cannot be underplayed as shown by Escobar since it (development) should be considered as a process that is rooted in people's history and cultural tradition. It is at this point that he castigates some scholars who failed to understand the development of the societies in the Global South from the realms of their history and culture by saying that 'understanding the history of the investment 
of the Third World by Western forms of knowledge and power is a way to shift the ground somewhat so that we can start to look at that materiality with different eyes and in different categories' (Escobar 1997: 92). ${ }^{3}$

In his project for the making and unmaking of development for the societies in the Global South, Escobar points out fundamental importance and 'roles of grassroots movements, local knowledge, and popular power in transforming development' (Escobar 1995: 215). That is, an interest in local culture and knowledge; a critical stance with respect to established scientific discourses; and the defence and promotion of localized, pluralized grassroots movements' (Ibid.: 215-216). Escobar foresees many problems inherent in these alternatives, which is in the complicit of cultures in the Third World in the quest for development re-engineering. He notes,

\begin{abstract}
At the bottom of the investigation of alternatives lies the sheer fact of cultural difference. Cultural differences embody - for better or for worse, - possibilities for transforming the politics of representation, that is, for transforming social life itself... Because cultural difference is also at the root of post-development, this makes the reconceptualization of what is happening in and to the Third World a key task at present. The unmaking of the Third World - as a challenge to the Western historical mode to which the entire globe seems to be captive - is in the balance (Ibid.: 225).
\end{abstract}

Seeing this great challenge, Escobar proffers solutions to this tragic task and problem, in two forms and principles: 'the defence of cultural difference, not as a static but as a transformed and transformative force; and the valourization of economic needs and opportunities in terms that are not strictly those of profit and market' (Ibid.: 226).

THE SIGNIFICANCE OF CULTURAL KNOWLEDGE IN DEVELOPMENT AND SOCIAL ORDER

Everything that a human perceives, knows, thinks, values and feels is learned through his participation in a cultural system. This means that human potentials can only be realized within the structure of human culture and through growing up in close contact with other human beings in the society. Culture is understood as a complex and broad set of relationships, values, attitudes and behaviours that binds together a specific community consciously and unconsciously. This is because people are born into specific culture with prevailing values and opportunities, which are expressed in their diverse institutions, arts and learning.

Our understanding of culture will lead to an analysis of what cultural knowledge is all about. This is because cultural knowledge cannot exist in a vacuum as it has to be based and established in the culture of a people. That is to say cultural knowledge is preserved in the culture of the people and is used for human survival. This is predicated on the fact that culture is a source of innovation, identity and creativity. As source of eve- 
rything that people are involved in either at the local or global level, the onus therein suggests that each culture projects particular knowledge which an individual uses for his/her survival.

It is important to state from the very beginning there existed the problem of semantics in the discourse of cultural knowledge. This is due to the fact that there are various terminologies as listed below which are used depending on the tradition to which each scholar or theorist belongs and that is the main reason why the term may have different characteristics such as indigenous, localised, rural and even traditional knowledge, among others, to establish the position of diverse views and opinions of authors and traditions involved. But here, we must clearly point out that those concepts and meanings, used interchangeably, are forms of experiential knowledge based on a worldview and culture, which is basically relational as it under-scores the totality of social human practices. They (terms and concepts) derive from cultural knowledge, that is, they are based on particular culture and so they are experiences of what transpire in such cultural background. Such relational aspect of culture suggests that it covers the wholeness and the community structure of all in any given society, which is embedded in cultural values. This is to state that acquisition of knowledge is a collective and community-initiated and integrated process stating unequivocally that cultural knowledge embraces other possible types of knowledge.

Cultural knowledge is the agent, which binds society together. This is due to the fact that it constitutes communicative processes through which knowledge is acquired, preserved and transmitted by people of different societies and at different stages of life. It is the information base for a society, which facilitates communication and decision-making. This means that the basic composition of any society's knowledge system is its cultural knowledge. These knowledge forms are known under other names, and among others they are localized knowledge, indigenous ways of knowing, traditional knowledge, indigenous technical knowledge, and rural knowledge, etc.

The significance of knowledge in any human endeavour and its efficacy to the understanding of who the people are and what they hope to be in the future can never be under-played as it is the fulcrum on which the society rests and builds on. It is in this realm that Kwasi Wiredu reiterates the importance and significance of knowledge to human survival and endeavour, saying that 'Knowledge is necessary for action. That is axiomatic. Action is necessary for survival. That too is axiomatic. Therefore, most certainly, knowledge is necessary for survival' (Wiredu 1998: 17). He argues further that

The quest for knowledge of any type is a characteristically human endeavour. In the changes and chances of human history some peoples may come to be ahead of others at some particular point of time in some particular area of investigation, but there is nothing to show 
that such situations must be permanent; and there is also no reason why any form of genuine knowledge should be attributed to any peoples in any proprietary sense (Wiredu 1998: 17).

For the survival of human race and that of any society, knowledge is sacrosanct and it differs from one society to another as different societies have different problems. This ultimately leads to the fact that a society's knowledge determines the way this society exists and earns its living.

Although the scholars adhering different approaches like Hountondji have problems with defining collective knowledge calling it ethnophilosophy, this does not in any way rule out the possibility and actuality of collective form of knowledge. Leszek Nowak (2005: 117) argues that 'To Western thought one of the most surprising properties of African thought is the idea of ascribing knowledge to certain kinds of collective subjects - such as family lines.' He states unequivocally that 'It is hardly true that epistemological collectivism is the peculiarity of African thought. It first became apparent in the European thought with Hegel, and manifests itself wherever the Hegelian influence is or was discernible...' (Nowak 2005: 117). In order to justify his argument that Hegelian thought essentially is collective in nature, he brings out the fact that

The belief that the collective point of view is inherent in the epistemic perspective of Marxism is very frequent among Marxists; Marxism then concentrates not on individuals' characteristics, but on larger wholes: classes, strata, entire societies. The epistemic subject then is not this or that individual, but a collective subject, equal to the sets of all societies of a given historical era' (Ibid: 119 ; the emphasis is ours).

These claims point to the fact that collective form of knowledge is not place-oriented, that is, it is not about a particular community or culture. Collective knowledge exists in all societies of the world. Thus, any foreign or alien form of knowledge should not be superimposed on the cultural knowledge, even if such form of knowledge can be useful for the survival of human endeavours as there is no crime in borrowing knowledge from other countries.

Cultural knowledge begins with the understanding that there are differences among cultures, which includes placing value on the forms of diversity concerning the ideas inherent in individual cultural backgrounds. This understanding allows for cultural sensitivity that cultural differences and similarities exist without necessarily assigning values either right or wrong, better or worse to such differences. In this process, cultural knowledge undergoes various forms of awareness, which involves internal changes in terms of attitudes and values, which in one way or the other refers to those fundamental qualities of openness and flexibility, which necessarily exist and which people develop in relation to others. Thus, Amilcar Cabral argues that cultural knowledge is the quest for identity and liberation 
from domination, imperialism, oppression and humiliation. He understands culture as a form of ability to produce what is inherent in the historical past of the people. To him, it is 'in culture that you find the capacity (or responsibility) for the production and the fertilizing of the seed, which ensures the continuity of history, ensuring at the same time the perspectives of the evolution and the progress of the society in question' (Cabral 1974: 13). This understanding is used to examine the value of those fundamentals residing in culture as a product of history in the quest for emancipation and development. Here, he avers that

The value of culture as an element of resistance to foreign rule lies in the fact that, in the ideological or idealistic context, it is the vigorous manifestation of the materialist and historical reality of the society already under domination, or about to be dominated...

Culture, whatever may be the ideological or idealistic manifestations of its character, is thus an essential element in the history of a people. It is, perhaps the product of history as the flower is the product of a plant... culture teaches us what have been the dynamic syntheses, structured and established by the mind of society for the solution of these conflicts, at each stage in the evolution of this same society in the quest for survival and progress (Cabral 1974: 13).

In this quest for the emancipation, development and social order of a society from aliens and slave-owners from within, Amilcar Cabral proffers a better understanding of cultural knowledge in the struggle for the achievement of this set-objective without which the crave for liberation will be fruitless. Here, he writes

... the liberation movement must base its programme on profound knowledge of the culture of the people, and it must be able to appreciate the elements of this culture, giving to each its due weight, and also, appreciate the various levels it has reached in each social category. It must also be able to discern the essential from the secondary, the positive from the negative, the progressive from the retrogressive, the strengths from the weaknesses, in the total cultural complex of the peoples. All this, with a view to the various demands of the struggle, and with an aim of being able to concentrate its efforts on the essential without forgetting the secondary, to arouse the development of positive and progressive elements and to resist flexibility but stoutly, negative and retrogressive elements; and finally, with a view to utilizing the strengths and eliminating the weaknesses or transforming the latter into strengths (Cabral 1974: 16).

On the other hand, Cabrale also suggests the adaptation of strategic techniques for the survival of the society. It should be pointed out that 
without the consideration of the local knowledge of the people, moving out of the 'woods' will definitely be impossible. Thus, he states that

The liberation movement must be able to bring about slowly but surely, in the course of political programme, a convergence of the levels of culture of the various social categories, which can be deployed for the struggle, and to transform them into a single national cultural force, which acts as the basis and the foundation of the armed struggle... Knowledge of the struggle shows just how utopian and absurd it is to pretend to apply methods adopted by other peoples during their wars of liberation and the solutions, which they found to problems with which they were or are faced, without considering the facts of the locale... (Cabral 1974: 16)

Developing a culturally competent attitude is an ongoing process. It is important to view all people as unique individuals and realize that their experiences, beliefs, values and language affect their ways of interacting with others and the larger community. Also, one must be aware that differences exist within cultures and they stipulate the emerging differences and divergences in human societies. This shows that cultural knowledge is all about self-identity and self-determination without which an individual will be a stranger to his environment.

In this struggle for self-identification as argued above, cultural knowledge proposes that it is also about values in cultural traits of a society. These values might be in form of Ubuntu theory, social ethics among the peoples of southern part of Africa, which stipulates that society, not a transcendent being, gives human beings their humanity. It is a known fact from this pattern that people with high personal and social identity rely on their stable, internal values as a guide to their social behaviour, which in one way or the other focus on their strong sense of national pride, and family heritage that build upon their sense of collectiveness and bond in the society. It is a re-affirmation of John Mbiti's I am, because We are and, since we are, therefore, I am. This means that there is no human survival without the support of others in the society, that is, an individual is a community being from birth to death. This is an affirmation of one's humanity through the humanity of others because it is what sustains the regeneration of humanity through socialization. Socialization presupposes a community population with which individuals have vested interests in the collective prosperity of what affects the community. Even though it caters for the community interests, this does not in any way or manner isolate the interests of the individuals in the society.

In our quest for the understanding of cultural knowledge and its efficacy in societies of the world either of the Global North or of the Global South, some factors are of utmost importance. And here, Mariano Grondona examines some factors/values that must be embraced for the survival of such community and which are ultimately linked to the performance 
of the cultures involved. The implication is that if people in such cultural backgrounds avail themselves of those salient factors/values like: religion, trust, the moral imperative, the notion of justice, the value of work (dignity of labour), and importance of time among others (Grondona 2000) as listed in his twenty contrasting cultural factors, the better for such society. Those values are to serve, according to him, as 'a bridge between shortterm and long-term expectations, decisively reinforcing distant goals in their otherwise hopeless struggle against instant gratification' (Ibid.: 46). This is the point by which culture and all the embedded traits play significant role in the molding of individuals, in the struggle and quest for development and social order of the human community. This means that social changes can only be understood on the basis of cultural knowledge as it is achieved through the development of abilities, attitudes and other forms of behaviour, which are positive to the community's values. And because it reproduces new ideas and abilities in the process of solving problems, it involves a process of total 'religious' re-orientation and teaching that help people to think for themselves, to implement their projects and to find long-term and lasting solutions to their community's problems.

This understanding of cultural knowledge raises the argument in favour of social re-engineering in the society. By this, social re-engineering is understood from the realm of evolution, that is, the theory of human progression, which each society of the world needs in order to survive and improve its status. Alfred Reginald Radcliffe-Brown argues that

The idea of progress is that of improvement, the betterment of human life. The idea of evolution is a neutral scientific concept and does not imply movement in a desirable direction. Social evolution, like organic evolution, is conceived as being essentially a process of diversification. By it new and different forms of societies are produced. The evolutionist is interested in studying the processes of the diversification of societies. It is, I hope, evident that they cannot be explained by the 'diffusion of culture'. Although the theory is that in human life taken as a whole there has been a process of evolution, it is recognized that what Spencer called 'retrogression' frequently occurs in particular instances. For the theory of social evolution the processes called 'diffusion of culture' or 'acculturation' are only parts or aspects of what Spencer called a 'factor of extreme importance' in social evolution, evolution, the action and reaction between a society and other societies with which it is, or comes to be, in contact or communication (Radcliffe-Brown 1947: 80-81).

This analysis by Radcliffe-Brown suggests that there is a closer link between evolutionary discourse and human development. This is because evolution, in whatever means, is a theory of human survival and improvement. And according to it, there is no way a human can dissociate 
himself from the culture in which he lives; in other words, there is a relationship when discussing about evolution and the progression or improvement of an individual and the society.

\section{CONCLUSION}

The cultural knowledge, as argued in this study, is concerned with the study of value systems and structural functioning of a people, which is considered as a method as well as a programme of human beings and system of thinking designed to improve people's living conditions. In the process of problem solving, cultural knowledge helps society to develop skills in order to assess the relative importance of problems they face and to choose appropriate actions available to them in dealing with their problems without necessarily looking outside for solutions. Based on this understanding, cultural knowledge as shown, guides the process of development for particular set of goals, which further lays emphasis on the achievement of certain objectives and procedures set and organized by the people. Hence, it becomes the means of educating the community in the process of development. This shows the significance of cultural knowledge to the improvement and progression of human society, which in itself is linked to the discourses of anthropologists' evolution either in its scientific and social dimensions.

However, the post-development theory alongside with Escobar's ethnocentric model is insufficient for the development in Africa because it is a kind of cultural relativism, which is capable of veering into fundamentalism and does not allow for mutual borrowing from other cultural backgrounds. This does not mean that lending from outside the cultural background is a crime but that any 'foreign or alien' form of knowledge should not be super-imposed on the cultural knowledge, even if such form of knowledge could be useful for the survival of human endeavours. But this idea of borrowing from outside one's culture should be to add value to what is and not to discard it entirely. Therefore, a combination of cultural knowledge and Western development theories through an adaptation of the post-development theory is needed for the development in Africa particularly. This means that an all-inclusive model encapsulating life promotion and centered on man as both the subject and object should be adopted as a model of development for Africa.

\section{NOTES}

${ }^{1}$ Endogenous development implies a refutation of the view of development $=$ modernization $=$ Westernization .

${ }^{2}$ It presents a conventional and narrow view of globalization, equated with homogenization.

${ }^{3}$ To be sure, there is a situation of economic exploitation that must be recognized and dealt with. Power is too cynical at the level of exploitation and should be resisted on its own terms. There is also a certain materiality of life conditions that is extremely 
preoccupying and that requires great effort and attention. But those seeking to understand the Third World through development have long lost sight of this materiality by building upon it a reality that, like a castle in the air, has hunted us for decades. $C f$. also Escobar 1995: 53.

\section{REFERENCES}

Andreasson, S. 2007. Thinking Beyond Development: The Future of Post-Development Theory in South Africa. A draft paper for British International Studies Association Annual Conference University of Cambridge, 17-19 December.

Cabral, A. 1974. National Liberation and Culture. Transition 45: 12-17.

Escobar, A. 1995. Encountering Development: The Making and Unmaking of the Third World. Princeton: Princeton University Press.

Escobar, A. 1997. The Making and Unmaking of the Third World through Development. In Rahnema, M., and Bawtree, V. (eds.), The Post-Development Reader (pp. 85-93). London: Zed Books.

Escobar, A. 1999. The Invention of Development. Current History 98 (631): 382-386.

Grondona, M. 2000. A Cultural Typology of Economic Development. In Harrison, L., and Huntington, S. (eds.), Culture Matters: How Values Shape Human Progress (pp. 47-53). New York: basic Books.

Karplus, L. 2014. Post-Development Theory and Food Security: A Case Study in Swaziland. Capstone Projects - Politics and Government 20: 5.

Kothari, U., and Minogue, M. 2002. Critical Perspectives on Development: An Introduction. In Kothari, U., and Minogue, M. (eds.), Development Theory and Practice (pp. 1-15). Hampshire: Palgrave Macmillan.

Matthews, S. 2004. Post-Development Theory and the Question of Alternatives: A View from Africa. Third World Quarterly 25 (2): 373-384.

Nowak, L. 2005. On the Collective Subjects in Epistemology: The Marxist Case and a Problem for the African Viewpoint. In Hamminga, B. (ed.), Knowledge Cultures: Comparative Western and African Epistemology (Poznan Studies in the Philosophy of the Sciences and the Humanities, Vol. 88) (pp. 117-128). New York: Rodopi.

Peet, R., and Hartwick, E. 2009. Theories of Development: Contentions, Arguments and Alternatives. New York and London: Guilford Publications.

Pieterse, J. 2001. Development Theory: Deconstructions/Reconstructions. London: Sage Publications.

Radcliffe-Brown, A. R. 1947. Evolution, Social or Cultural? American Anthropologist 49: 80-81.

Rist, G. 2008. The History of Development: From Western Origins to Global Faith. London and New York: Zed Books.

Siemiatycki, E. 2005. Post-Development at a Crossroads: Towards a 'Real' Development. Undercurrent: Canadian Journal of Development Studies II (3): 58.

Wiredu, K. 1998. Our Problem of Knowledge: Brief Reflections on Knowledge and Development in Africa. In Oladipo, O. (ed.), Remaking Africa: Challenges of the Twenty-first Century (pp. 271-295). Ibadan: Hope Publications. 